\title{
Pertumbuhan Bibit Cendana (Santalum album L.) dengan Inang Primer pada Intensitas Radiasi Berbeda
}

\section{(The Growth of Sandalwood Seedlings (Santalum album L.) with Primary Hosts at Different Radiation Intensities)}

\author{
Yudi Riadi FanggidaE, Impron*, Tania June
}

(Diterima November 2018/Disetujui Juni 2020)

\begin{abstract}
ABSTRAK
Inang primer bibit cendana (Santalum album L.) yang paling banyak digunakan dalam proses pembibitan adalah Alternanthera sp., namun penyebutan nama lokal tanaman ini di masyarakat NTT sama dengan tanaman Portulaca sp. Nama lokal yang sama memungkinkan terjadi kesalahan dalam penggunaan inang primer pada saat budi daya bibit cendana, sementara kemampuan Portulaca sp. sebagai inang primer belum diketahui. Penelitian ini bertujuan untuk membandingkan pertumbuhan bibit cendana yang ditanam dengan inang primer Alternanthera sp. dan Portulaca sp. pada kondisi intensitas radiasi yang berbeda. Rancangan percobaan penelitian menggunakan rancangan acak lengkap dengan dua faktor perlakuan, yaitu perbedaan tingkat naungan (tanpa naungan, 25, 50, dan 75\%) dan perbedaan jenis inang primer. Data yang diperoleh dianalisis dengan analisis sidik ragam (ANOVA) dan uji Duncan. Hasil penelitian menunjukkan inang primer Alternanthera sp. memberikan pertumbuhan yang paling baik bagi bibit cendana dibandingkan dengan bibit cendana yang ditanam dengan inang primer Portulaca sp. Pemberian naungan harus disesuaikan dengan jenis inang primer yang digunakan. Bibit cendana yang ditanam dengan inang primer Alternanthera sp. bertumbuh paling baik pada kondisi naungan paranet $50 \%$ dan $75 \%$, yaitu pada kisaran radiasi sebesar 9,86-12,17 $\mathrm{MJ} / \mathrm{m}^{2} /$ hari. Bibit cendana yang ditanam dengan inang primer Portulaca sp. bertumbuh paling baik pada kondisi naungan paranet $25 \%$, yaitu pada rata-rata radiasi sebesar $13,62 \mathrm{MJ} / \mathrm{m}^{2} / \mathrm{hari}$. Penggunaan inang primer Alternanthera sp. dan pemberian naungan (50-75\%) sangat direkomendasikan dalam budi daya bibit cendana.
\end{abstract}

Kata kunci: cendana, haustoria, hemiparasit, inang primer, simbiosis

\section{ABSTRACT}

The primary host of sandalwood seeds (Santalum album L.) which is widely used in the nursery process is Alternanthera sp. However, the local name given to this primary host is same as that given to Portulaca sp. The same local name for these two-different species may cause mistakes in the use of the primary host during the cultivating process of sandalwood. Meanwhile, the ability of the Portulaca sp. as the primary host is unknown. Information about the right radiation intensity of the sandalwood seedling is still limited. The study aims to analyze the growth of sandalwood seedlings grown with primary host of Alternanthera sp. and Portulaca sp. at different radiation intensities. The completely randomized design with two treatments factor were used, namely differences in shade levels (without shade, 25, 50, and 75\%) and differences in the types of primary hosts. The result showed that the primary hosts of Alternanthera sp. have the best growth for sandalwood seeds compared to sandalwood seedlings planted with Portulaca sp. The shading must be adjusted to the type of primary host. Sandalwood seeds grown with Alternanthera sp. as primary hosts grow best at $50 \%$ and $75 \%$ paranet shade conditions, in radiation range of $9.86-$ $12.17 \mathrm{MJ} / \mathrm{m}^{2} /$ day. Sandalwood seeds planted with Portulaca sp. as a primary host grow best in $25 \%$ paranet shade, that is at average radiation of $13.62 \mathrm{MJ} / \mathrm{m}^{2} /$ day. The use of Alternanthera sp. and shade provision (50-75\%) is highly recommended in sandalwood seedlings.

Keywords: haustoria, hemiparasite, primary host plant, sandalwood, symbiosis

\section{PENDAHULUAN}

Cendana (Santalum album L.) merupakan tanaman khas Nusa Tenggara Timur (NTT) yang bernilai ekonomi tinggi. Bagian batang dan akar tanaman

\footnotetext{
Sekolah Pascasarjana, Fakultas Matematika dan Ilmu Pengetahuan Alam, Institut Pertanian Bogor, Kampus IPB Darmaga, Bogor 16680

2 Departemen Geofisika dan Meteorologi, Fakultas Matematika dan IImu Pengetahuan Alam, Institut Pertanian Bogor, Kampus IPB Darmaga, Bogor 16680

* Penulis Korespondensi: Email: impron@gmail.com
}

cendana memiliki aroma wangi yang dapat diekstrak untuk menghasilkan minyak atsiri yang banyak digunakan sebagai bahan baku dalam industri farmasi dan kosmetik. Selain dapat diekstrak untuk menghasilkan minyak, kayu cendana juga banyak digunakan sebagai bahan kerajinan tangan (Arun et al. 2012). Eksploitasi tanaman cendana yang tinggi yang tidak diimbangi dengan upaya pelestariannya menyebabkan tanaman ini menghadapi risiko kepunahan. Berdasarkan CITES (Convention international trade in endangered species of wild flora and fauna) populasi cendana di Indonesia 
telah masuk dalam kategori rawan yang berisiko tinggi mengalami kepunahan (Dhanya et al. 2010; Njurumana et al. 2014). Berbagai program kemudian telah dilaksanakan oleh pemerintah daerah untuk mengembalikan populasi cendana di NTT, namun tingkat keberhasilan penanaman di lapangan masih sangat rendah, yaitu kurang dari 50\% (Surata 2012). Hingga saat ini, masih belum banyak terdapat hutan cendana di NTT, bahkan Indonesia belum mempunyai pengalaman dalam pengusahaan hutan cendana sehingga sistem silvikultur yang tepat dalam budi daya tanaman cendana juga belum diketahui (Husaeni \& Sudaryanto 2001).

Cendana merupakan tanaman yang bersifat hemiparasit akar, yang ditandai dengan pembentukan haustoria yang akan menghubungkan akar cendana dengan tumbuhan lainnya (FanggidaE \& Impron 2018). Sifat hemiparasit ini mengakibatkan tanaman cendana selama masa pertumbuhan memerlukan kehadiran tumbuhan lain di sekitarnya yang berperan sebagai inang untuk memasok sebagian unsur hara dan air (Rahayu et al. 2002; Wawo 2004). Inang tanaman cendana terbagi atas inang primer yang diperuntukkan bagi pertumbuhan bibit cendana dalam polibag pada tingkat awal pertumbuhan dan inang sekunder yang dibutuhkan untuk pertumbuhan lanjutan di lapangan (Wawo 2009).

Penelitian Surata (1993) menunjukkan bahwa Alternanthera sp. yang disebut dengan nama krokot, sebagai inang primer yang paling baik dalam pembibitan cendana. Alternanthera sp. kemudian digunakan secara luas sebagai inang primer pada pembibitan cendana. Penggunaan nama Krokot pada Alternanthera sp. dalam penelitian Surata (1993) ternyata berbeda dari tanaman lokal yang selama ini diketahui oleh masyarakat di NTT. Nama lokal krokot lebih dikenal pada tanaman Portulaca sp. yang merupakan tanaman lokal di daerah NTT dan sebagian Jawa. Portulaca sp. merupakan tanaman sukulen tahunan yang masuk ke dalam keluarga portulaceae yang dapat dikonsumsi sebagai sayuran (Erkan 2012). Nama lokal yang sama antara Alternanthera sp. dan Portulaca sp. memungkinkan terjadi kesalahan dalam penggunaan inang primer pada saat budi daya bibit cendana. Hingga saat ini, belum ada penelitian yang ditemukan mengenai kemampuan Portulaca sp. sebagai inang primer bibit cendana.

Penelitian terdahulu mengenai budi daya bibit cendana menyebutkan bahwa bibit cendana tidak tahan pada terpaan sinar matahari langsung sehingga membutuhkan naungan (Boer \& June 2001). Naungan diperlukan oleh bibit cendana hingga tanaman tersebut dipindahkan ke lapangan dan selanjutnya naungan dikurangi secara bertahap. Naungan yang terlalu besar pada masa pertumbuhan cendana dapat menyebabkan gangguan pertumbuhan (Surata \& Butarbutar 2008). Informasi terkait jumlah naungan yang tepat selama masa pembibitan cendana hingga saat ini masih belum banyak ditemukan sehingga dalam penelitian ini akan dilakukan pengamatan tentang pengaruh induk primer dan keadaan naungan pada pertumbuhan bibit cendana pada kondisi intensitas radiasi surya yang berbeda. Penelitian ini bertujuan untuk menganalisis dan membandingkan antara pertumbuhan bibit cendana yang ditanam dengan inang primer Alternanthera sp. dan Portulaca sp. pada kondisi intensitas radiasi yang berbeda sehingga dapat diketahui kombinasi yang paling baik bagi pertumbuhan bibit cendana.

\section{METODE PENELITIAN}

Penelitian ini dilakukan pada bulan Desember 2017-Mei 2018 di Kupang, Nusa Tenggara Timur. Bibit cendana yang digunakan dipilih secara seragam yang berumur 3 bulan dengan kriteria tinggi tanaman 20-25 $\mathrm{cm}$ dan jumlah daun yang telah membuka sempurna sebanyak 10-12 lembar. Penyiapan inang primer dilakukan secara terpisah. Stek batang Alternanthera sp. dan Portulaca sp. disemaikan 2 minggu sebelum penanaman cendana dengan inangnya hingga mencapai tinggi $10 \mathrm{~cm}$. Bibit cendana dan inang primer ditanam bersama-sama dalam wadah tanam yang telah disiapkan. Media tanam yang digunakan berupa tanah, pasir, dan pupuk kandang yang dicampur secara merata dengan perbandingan 1:1:1. Stek Alternanthera sp. dan Portulaca sp. ditanam pada jarak $10 \mathrm{~cm}$ dari bibit cendana. Bibit cendana bersama inang primernya kemudian ditempatkan pada kelompok naungan yang berbeda. Naungan yang digunakan adalah naungan paranet dengan kelompok kerapatan 25,50 , dan $75 \%$. Satu kelompok lainnya merupakan kondisi tanpa naungan. Solarimeter ditempatkan di bawah naungan untuk mengukur intensitas radiasi yang diterima tanaman.

Rancangan yang digunakan pada penelitian adalah rancangan percobaan dengan dua faktor perlakuan, yaitu perbedaan tingkat naungan dan perbedaan jenis inang primer. Faktor pertama terdiri atas empat taraf perlakuan, yaitu kondisi tanpa naungan (N0), naungan paranet $25 \%$ (N1), 50\% (N2), dan $75 \%$ (N3). Faktor kedua terdiri atas tiga taraf perlakuan, yaitu bibit cendana yang ditanam tanpa inang primer $(\mathrm{K})$, bibit cendana dengan inang primer Alternanthera sp. (CA), dan bibit cendana dengan inang primer Portulaca sp. (CP). Desain penelitian ditunjukkan seperti pada Gambar 1. Berdasarkan kedua faktor perlakuan maka diperoleh 12 kombinasi perlakuan dengan 9 ulangan sehingga total terdapat 108 unit pengamatan. Data yang diperoleh dianalisis dengan sidik ragam (ANOVA), apabila berbeda nyata akan dilanjutkan dengan uji lanjut Duncan (Duncan multiple range test).

Pengamatan dilakukan selama sembilan minggu dengan destruktif bibit cendana dilakukan tiga kali, yaitu pada umur 3,6 , dan 9 minggu setelah tanam bibit cendana bersama inang (MSTI). Waktu 9 minggu merupakan fase pembibitan cendana, selanjutnya bibit 


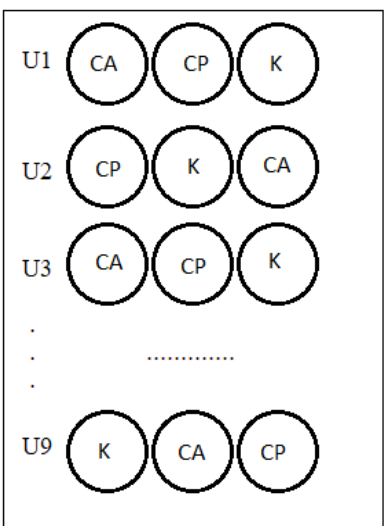

No

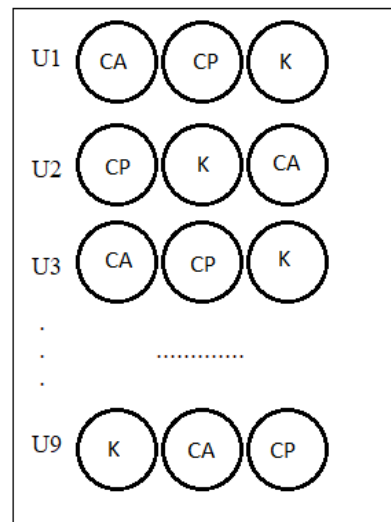

N1

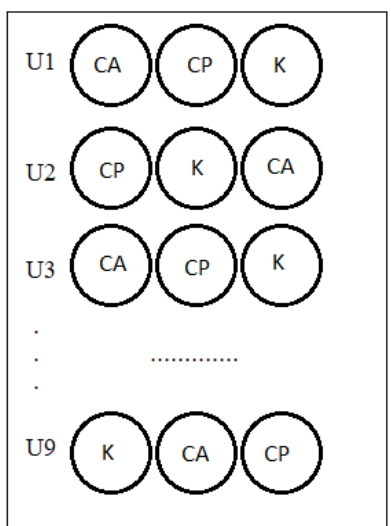

N2

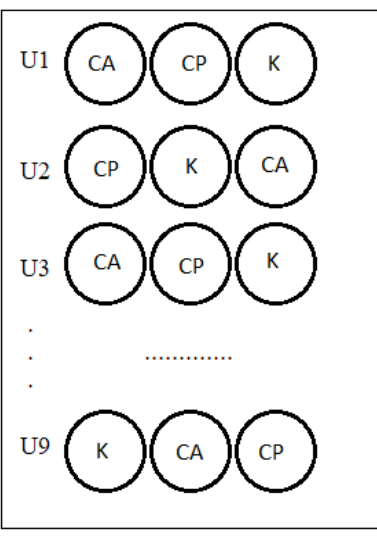

N3

Gambar 1 Denah tempat penanaman dan perlakuannya. N0 = Tanpa naungan, N1 = Naungan 25\%, N2 = Naungan $50 \%$, N3 $=$ Naungan $75 \%, \mathrm{~K}=$ Kontrol (cendana tanpa inang), $\mathrm{CP}=$ Cendana dengan inang primer Portulaca sp., dan CA = Cendana dengan inang primer Alternanthera sp.

cendana harus dipindahkan ke lapangan. Destruktif pada umur 3 dan $6 \mathrm{MSTI}$ dilakukan untuk melihat pengaruh faktor perlakuan pada masa awal ketika cendana tumbuh bersama inang dan pada masa sebelum waktu bibit cendana dipindahkan ke lapangan. Parameter lingkungan yang diamati adalah intensitas radiasi surya, sementara parameter pertumbuhan yang diamati sebagai respons terhadap perlakuan yang diberikan adalah 1) Tinggi tanaman, 2) Specific leaf area (SLA), 3) Kandungan konsentrasi klorofil, 4) Jumlah haustoria, dan 5) Biomassa bibit cendana.

Tinggi bibit cendana ditentukan dari pangkal batang hingga tunas pucuk, untuk menganalisis pertumbuhan bibit akibat faktor inang dan intensitas radiasi berbeda.

Specific leaf area (SLA) merupakan nilai yang menggambarkan luasan daun per satuan bobot kering daun (Anyia \& Herzog 2004). Luas daun bibit cendana ditentukan dengan metode scannmeter, selanjutnya $\mathrm{SLA}\left(\mathrm{cm}^{2} / \mathrm{g}\right)$ ditentukan dengan rumus:

$$
\text { SLA }=\frac{\text { Luas daun }}{\text { Bobot kering daun }}
$$

Kandungan klorofil daun diamati sebagai respons fisiologis bibit cendana. Kandungan klorofil ditentukan menggunakan metode Hiscox \& Israelstam (1979). Daun bibit cendana dari tiap kombinasi perlakuan direndam dalam larutan dimetilsulfoksida (DMSO; $\left(\mathrm{CH}_{3}\right)_{2} \mathrm{SO}$ ), selanjutnya konsentrasi klorofil ditentukan menggunakan spektrofotometer pada panjang gelombang 663 dan $645 \mathrm{~nm}$. Kandungan klorofil dihitung dengan rumus:

$$
\mathrm{Chl}=\mathrm{C} \times \mathrm{v} / \mathrm{w}
$$

\section{Keterangan:}

$\mathrm{Chl}=$ Jumlah klorofil

C $=$ Konsentrasi klorofil $\left(\mathrm{mg} \mathrm{L}^{-1}\right)$ dari hasil pembacaan spektrofotometer

$\mathrm{V} \quad=$ Volume ektraksi $(\mathrm{mL})$

$\mathrm{W} \quad=$ Merupakan bobot daun $(\mathrm{g})$
Haustoria merupakan diferensiasi sel akar bibit cendana yang menempel pada akar inang. Haustoria dapat teramati dengan mata secara langsung (Tennakoon \& Cameron 2006). Pengamatan dilakukan dengan menghitung jumlah haustoria yang terbentuk pada tiap kombinasi perlakuan. Biomassa kering bibit cendana merupakan bobot batang dan daun yang dikeringkan di dalam oven selama 8 jam dengan suhu $110^{\circ} \mathrm{C}$.

\section{HASIL DAN PEMBAHASAN}

\section{Intensitas Radiasi}

Pemberian naungan bertujuan untuk mengurangi intensitas radiasi sehingga semakin tinggi persentase naungan paranet maka jumlah radiasi yang ditransmisikan menjadi semakin rendah (Gambar 2). Hasil penelitian menunjukkan bahwa setiap kerapatan paranet secara nyata memberikan nilai transmisi radiasi yang berbeda dan rata-rata intensitas radiasi harian selama penelitian pada kondisi tanpa naungan (N0) adalah sebesar $15,16 \mathrm{MJ} / \mathrm{m}^{2}$. Pemberian naungan paranet sebesar $25 \%$ (N1) menyebabkan rata-rata intensitas radiasi harian berkurang sebesar $10 \%$ dari kondisi tanpa naungan menjadi $13,62 \mathrm{MJ} / \mathrm{m}^{2}$. Rata-rata intensitas radiasi harian pada naungan paranet $50 \%$ (N2) adalah sebesar $12,17 \mathrm{MJ} / \mathrm{m}^{2}$ yang artinya berkurang $20 \%$ dari kondisi N0, dan Paranet $75 \%$ (N3) berkurang $35 \%$ dari kondisi N0, yaitu menjadi 9,86 $\mathrm{MJ} / \mathrm{m}^{2}$.

Intensitas radiasi selama penelitian selalu berfluktuasi dan sangat bergantung pada kondisi atmosfer. Hujan merupakan salah satu faktor yang dapat menyebabkan penurunan intensitas radiasi, akibat dari adanya awan yang menghalangi sinar matahari. Berdasarkan Gambar 2 dapat dilihat bahwa curah hujan tinggi akan berdampak langsung pada penurunan nilai intensitas radiasi. Curah hujan yang tinggi terjadi pada waktu 30-40 hari setelah tanam dengan inang (HSTI) sehingga intensitas radiasi yang paling rendah juga terjadi pada waktu tersebut. Kondisi 


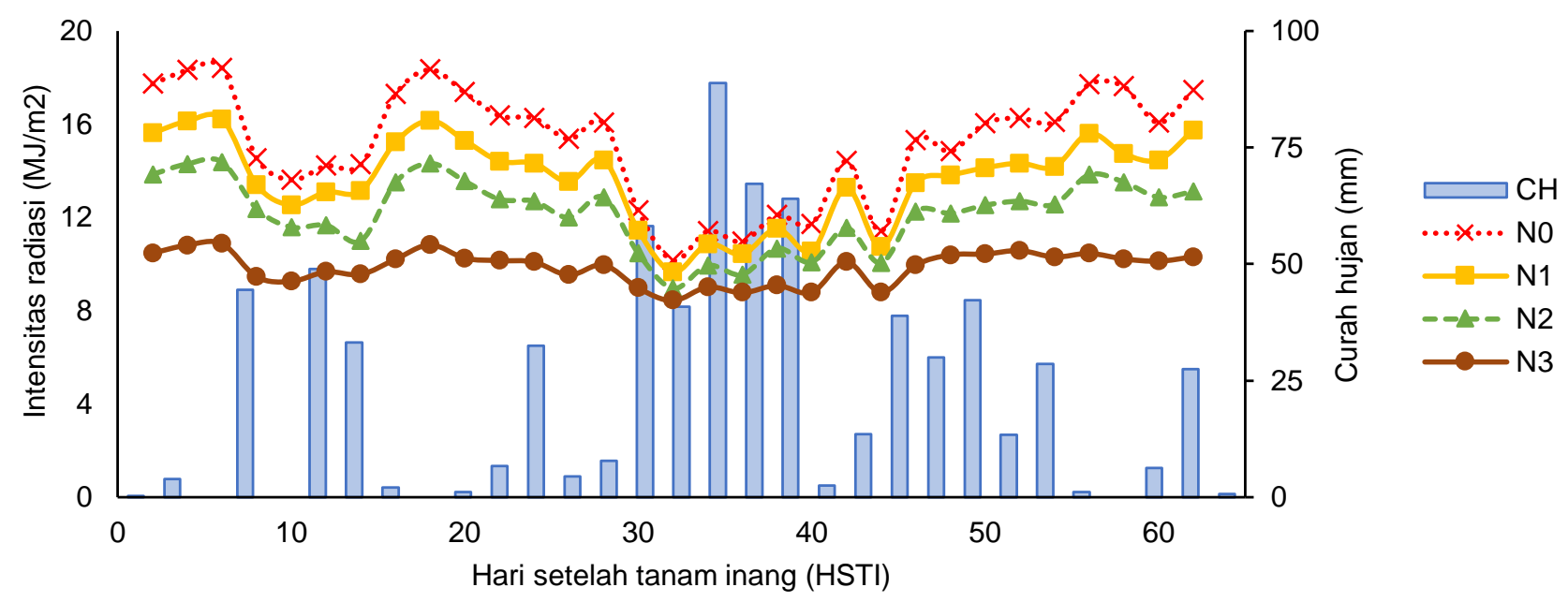

Gambar 2 Intensitas radiasi pada tiap kondisi naungan. N0 = Tanpa Naungan, N1 = Paranet 25\%, N2 = Paranet $50 \%$, N3 $=$ Paranet $75 \%$, dan curah hujan selama penelitian.

hujan menyebabkan radiasi langsung dari matahari menjadi rendah dan yang dominan adalah radiasi diffuse. Naungan kurang berpengaruh pada saat kondisi intensitas radiasi langsung rendah dan hal ini ditandai dengan perbedaan nilai intensitas yang kecil pada tiap kerapatan paranet. Sebaliknya, ketika tidak terjadi hujan, pengaruh pemberian naungan sangat jelas terlihat, yang ditunjukkan dengan perbedaan nilai intensitas yang besar antar-perlakuan paranet.

\section{Tinggi Bibit Cendana}

Pertambahan tinggi bibit cendana terjadi seiring dengan pertambahan umur bibit cendana (Gambar 3). Perbedaan tinggi tidak hanya terjadi akibat perbedaan radiasi yang diterima, tetapi jenis inang primer juga mempengaruhi tinggi bibit cendana. Tinggi bibit cendana yang ditanam tanpa inang (Gambar 3c) memiliki nilai yang paling rendah, sementara bibit cendana yang ditanam dengan inang Alternanthera sp. (Gambar 3a) memiliki nilai yang paling tinggi.

Pertumbuhan tinggi bibit cendana yang ditanam bersama inang primer Alternanthera sp. yang paling baik adalah pada kondisi N3. Hal ini berlangsung selama penelitian (Gambar 3a) dengan tinggi sekitar $52 \mathrm{~cm}$ pada 3 minggu setelah tanam bersama inang (MSTI), $76 \mathrm{~cm}$ pada $6 \mathrm{MSTI}$, dan $91 \mathrm{~cm}$ pada umur 9 MSTI. Kondisi NO yang ditanam tanpa inang adalah yang paling pendek selama penelitian (Gambar 3c). Data tinggi tanaman ini menunjukkan bahwa semakin rapat naungan yang diberikan berdampak pada peningkatan tinggi pertumbuhan bibit cendana.

Kekurangan intensitas radiasi mengakibatkan tanaman akan semakin cepat tumbuh tinggi ke arah datangnya sinar matahari. Pertambahan tinggi ke arah sinar matahari ini terjadi karena tanaman membutuhkan radiasi untuk proses fotosintesis. Pertambahan tinggi yang makin cepat pada kondisi ternaungi dapat terjadi karena hormon auksin untuk pertambahan tinggi tanaman akan semakin aktif pada kondisi yang semakin sedikit radiasi (Shehata et al. 2013). Keadaan inilah yang menyebabkan bibit cendana pada N3 memiliki laju pertumbuhan tinggi yang paling cepat sementara semakin menuju N0 laju pertumbuhan tinggi tanamannya semakin lambat.

\section{Specific Leaf Area}

Perbedaan radiasi yang diterima tanaman tidak hanya berpengaruh pada tinggi tanaman, tetapi juga berdampak pada ketebalan daun. Ketebalan daun ditentukan berdasarkan nilai luas per satuan bobot kering daun atau yang disebut dengan specific leaf area (SLA). Nilai SLA yang semakin kecil menunjukkan daun tanaman yang semakin tebal.

Ketebalan daun bibit cendana akibat pengaruh kombinasi perlakuan ditunjukkan pada Gambar 4. Daun bibit cendana yang ditanam dengan Alternanthera sp. memiliki pola yang sama dengan Portulaca sp., yaitu semakin tinggi naungan menyebabkan daun semakin tipis yang ditunjukkan dengan nilai SLA yang semakin besar pada tingkat naungan yang makin rapat. Daun yang lebih tebal pada kondisi No terjadi karena radiasi penuh berakibat pada suhu yang lebih tinggi sehingga meningkatkan transpirasi. Daun yang lebih tebal merupakan respons fisiologis pada jaringan tanaman untuk mengurangi transpirasi akibat suhu yang tinggi, sebaliknya pada kondisi ternaungi radiasi yang lebih rendah menyebabkan transpirasi yang terjadi lebih kecil sehingga penebalan daun tidak terjadi (Bergez \& Dupraz 2000).

Nilai SLA yang tinggi pada saat 3 MSTI pada bibit cendana yang ditanam dengan Alternanthera sp. di kondisi N2 dan N3 terjadi karena peningkatan luas daun yang semakin besar. Peningkatan luas daun terjadi sebagai respons tanaman terhadap kondisi radiasi yang rendah. Daun yang melebar merupakan bentuk adaptasi tanaman untuk meningkatkan penerimaan radiasi yang dibutuhkan dalam proses fotosintesis (Anyia \& Herzog 2004). Tanaman akan melebarkan daunnya pada kondisi ternaungi sepanjang kondisi lingkungan lain seperti unsur hara dan air mendukung. Hal ini menunjukkan bahwa nilai SLA yang tinggi pada N2 dan N3 (Gambar 3a) sebagai 


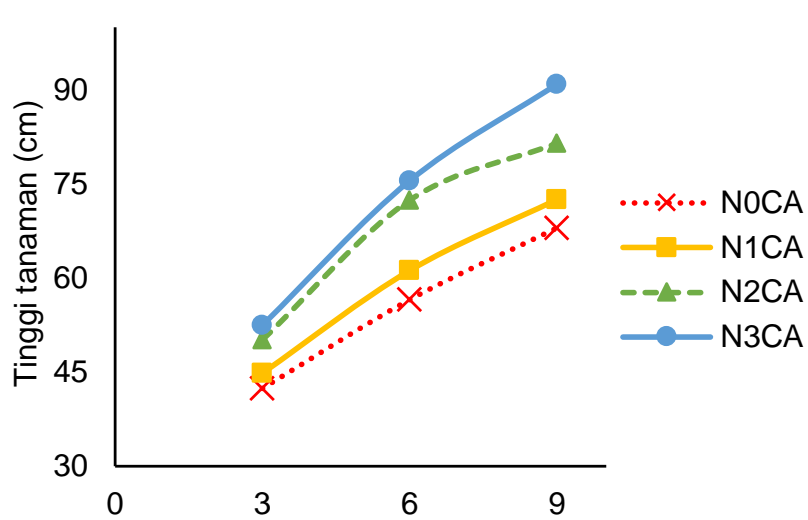

(a) Waktu (Minggu setelah tanam inang)
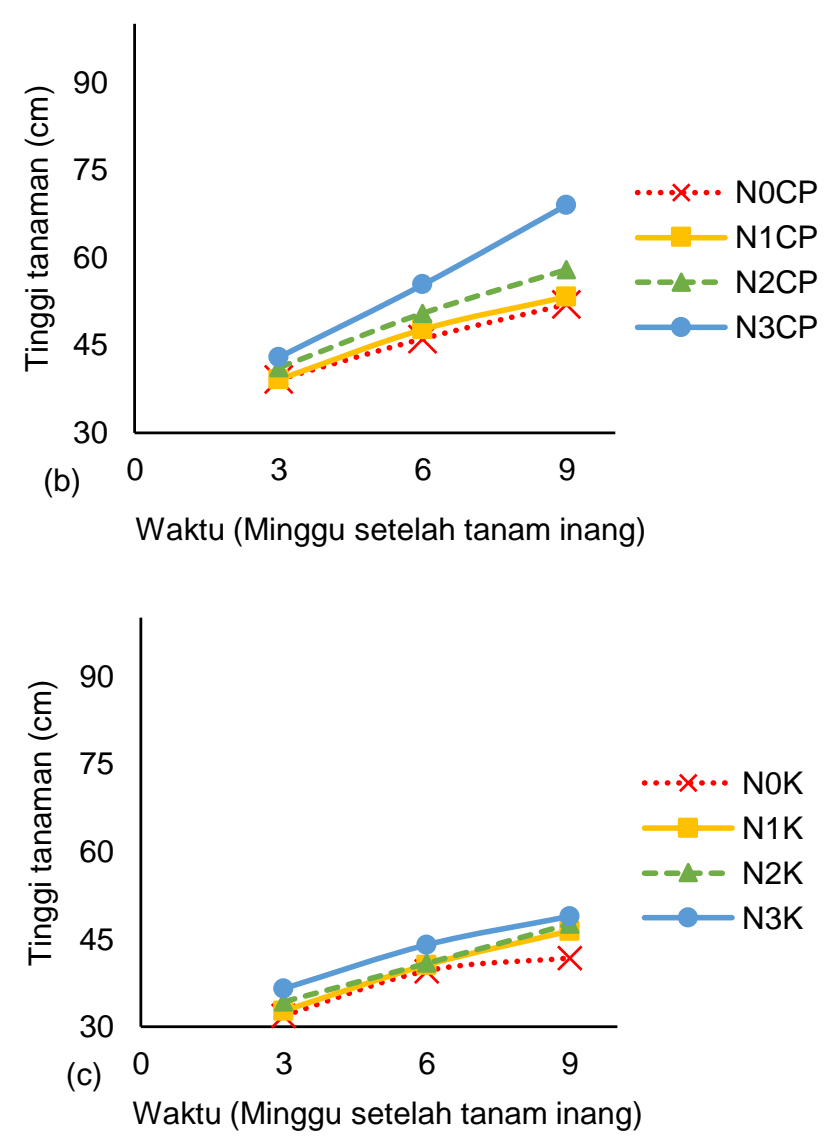

Gambar 3 Tinggi bibit cendana dengan inang primer Alternanthera sp. (a), dengan inang primer Portulaca sp. (b), dan tanpa inang primer (c), pada setiap kondisi naungan. N0 = Tanpa Naungan, $\mathrm{N} 1=$ Paranet $25 \%$, N2 = Paranet $50 \%$, N3 = Paranet $75 \%$, dan curah hujan selama penelitian.

indikasi hemiparasit yang baik telah terbentuk sejak 3 MSTI antara cendana dan Althernanthera sp. sehingga mampu mendukung pelebaran daun cendana.

\section{Kandungan Konsentrasi Klorofil}

Pengaruh perbedaan jenis inang primer dan perbedaan penerimaan radiasi tidak hanya diamati pada respons morfologi, tetapi juga fisiologi bibit cendana.

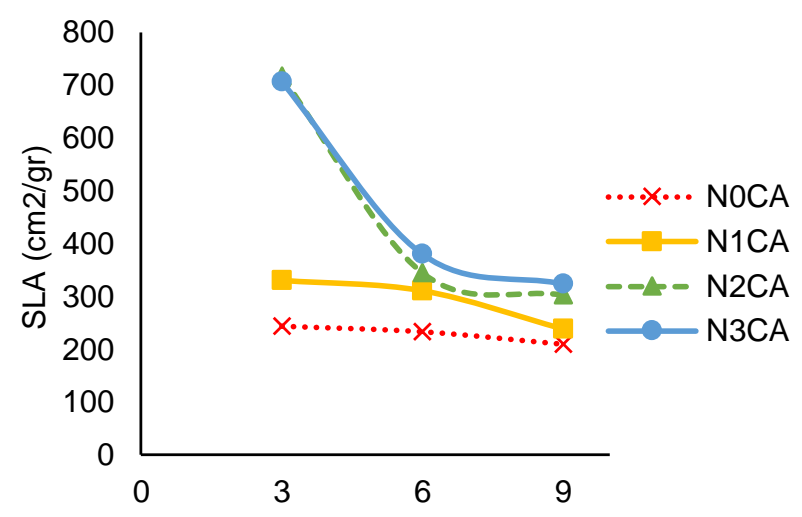

(a) Waktu (Minggu setelah tanam inang)
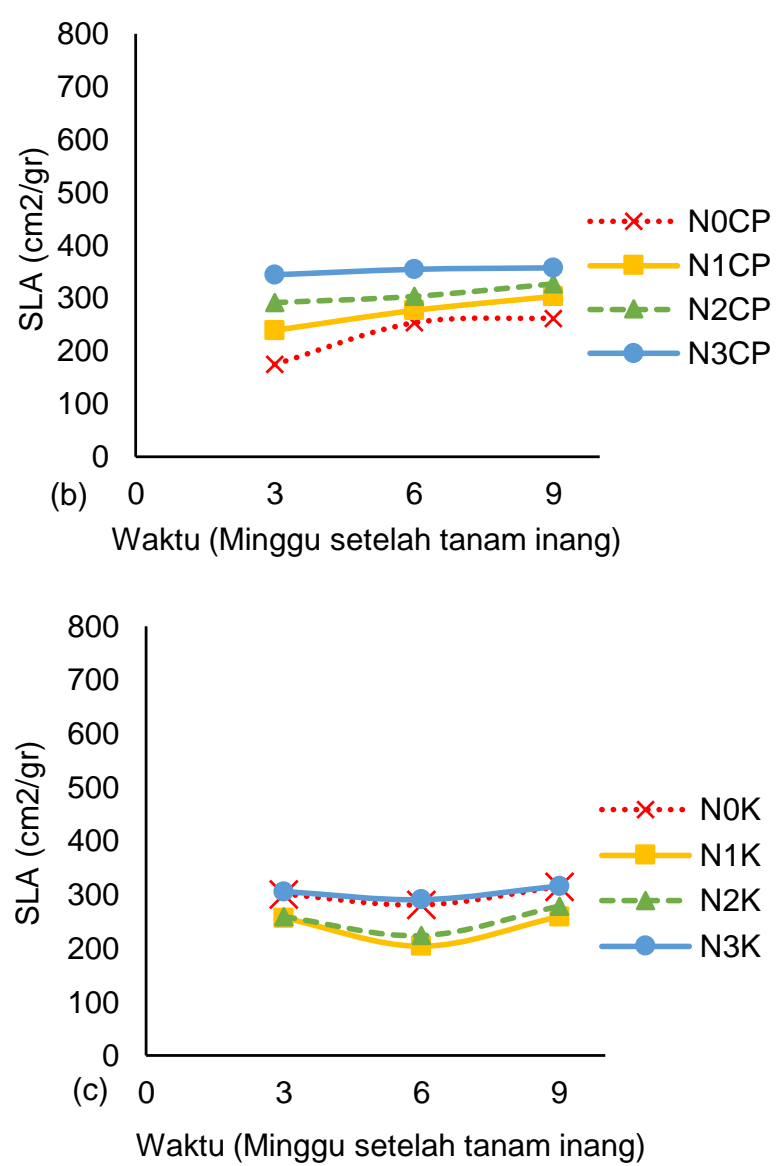

Gambar 4 Specific leaf area (SLA) bibit cendana dengan inang primer Alternanthera sp. (a), dengan inang primer Portulaca sp. (b), dan tanpa inang primer (c), pada setiap kondisi naungan (NO = Tanpa paranet, $\mathrm{N} 1=$ Paranet $25 \%, \mathrm{~N} 2=$ Paranet 50\%, dan N3 = Paranet 75\%)

Karakter fisiologi paling penting dari tanaman adalah kandungan konsentrasi klorofil pada daun. Klorofil berfungsi sebagai penangkap radiasi matahari untuk proses fotosintesis. Oleh karena itu, pengamatan klorofil sangat penting dilakukan untuk melihat pengaruh perlakuan yang diberikan.

Konsentrasi klorofil daun pada bibit cendana yang ditanam dengan masing-masing inang primer mem- 
berikan pengaruh dan pola yang berbeda (Gambar 5). Bibit cendana dengan inang primer Alternanthera sp. (Gambar 5a) memberikan respons peningkatan konsentrasi klorofil pada naungan yang semakin tinggi. Konsentrasi klorofil daun cendana dengan inang Alternanthera sp. pada naungan N2 dan N3 terus mengalami peningkatan seiring dengan pertambahan umur tanaman.

Konsentrasi klorofil bibit cendana pada Gambar 5 (b) menunjukkan bahwa bibit cendana yang ditanam dengan Portulaca sp. membutuhkan naungan, namun tidak dalam jumlah besar, yaitu pada rentang $\mathrm{N} 1$ dan N2. Naungan yang berlebihan memiliki pengaruh yang hampir sama dengan kondisi tanpa naungan yang ditunjukkan oleh garis yang berhimpitan pada NO dan N3 yang terus mengalami penurunan sejalan dengan pertambahan umur tanaman. Bibit cendana tanpa inang primer memiliki nilai konsentrasi klorofil yang terus menurun dengan pertambahan umur tanaman.

\section{Pengamatan Haustoria}

Karakter cendana sebagai tanaman hemiparasit ditandai dengan pembentukan haustoria pada akar yang berfungsi sebagai penghisap sebagian unsur hara dan air dari tumbuhan inang. Jika haustoria mampu membentuk kaitan dengan akar inang (Haustoria connection) maka haustoria tersebut akan tumbuh membesar (Yang et al. 2014). Jumlah haustoria yang terbentuk akibat kombinasi perlakuan yang diberikan pada akhir penelitian ditunjukkan pada Tabel 1.

Hasil uji DMRT pada Tabel 1 menunjukkan bahwa pemberian inang primer berpengaruh nyata pada jumlah haustoria yang terbentuk, sementara pemberian naungan tidak memiliki pengaruh nyata pada jumlah haustoria. Bibit cendana yang ditanam tanpa inang tetap membentuk haustoria, walaupun memiliki jumlah haustoria yang paling sedikit.

Berdasarkan Tabel 1 terlihat bahwa inang primer Alternanthera sp. memiliki pengaruh yang lebih baik pada pembentukan haustoria dibandingkan dengan Portulaca sp. Tanaman Alternanthera sp. memiliki jumlah akar serabut yang lebih banyak dibandingkan dengan Portulaca sp. Perbedaan ini diduga menjadi penyebab peluang pembentukan dan pertumbuhan haustoria menjadi lebih baik. Temuan ini sesuai dengan hasil penelitian FanggidaE \& Impron (2018) sebelumnya bahwa pada tanaman dengan akar serabut yang banyak memudahkan pembentukan hemiparasit antara cendana dan inang primer.

\section{Biomassa Tanaman}

Indikator yang paling penting untuk melihat pengaruh perlakuan pada pertumbuhan adalah biomassa kering tanaman. Biomassa bibit cendana yang diukur merupakan biomassa kering bibit cendana di atas permukaan, yaitu berupa biomassa batang dan daun. Haustoria yang terbentuk mengakibatkan akar inang dan akar cendana menjadi sulit untuk dibedakan.
Biomassa kering bibit cendana dari setiap kombinasi perlakuan ditampilkan pada Gambar 6.

Berdasarkan Gambar 6 terlihat bahwa semakin bertambah umur bibit cendana nilai biomassa semakin meningkat, dan pengaruh naungan pada nilai biomassa kering semakin terlihat. Keberadaan inang primer memiliki pengaruh yang lebih besar dibanding-

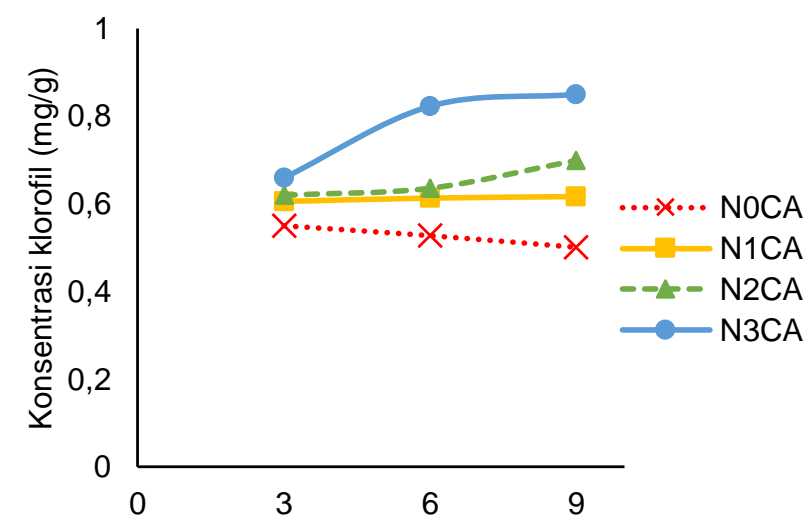

(a) Waktu (Minggu setelah tanam inang)

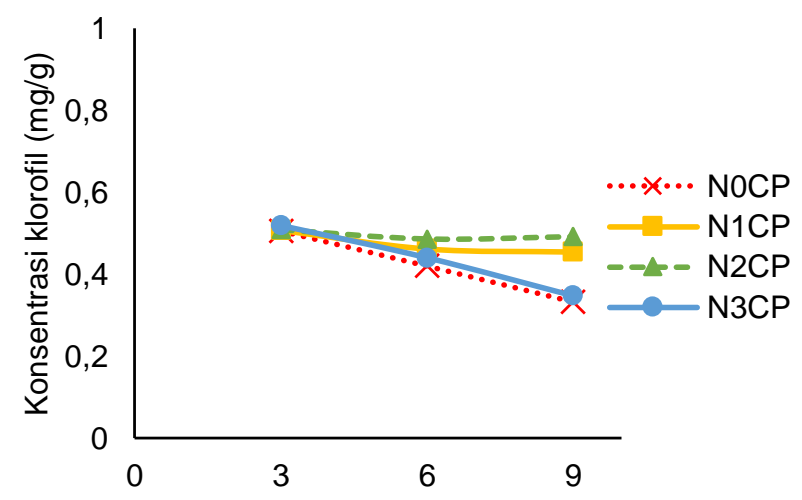

(b) Waktu (Minggu setelah tanam inang)

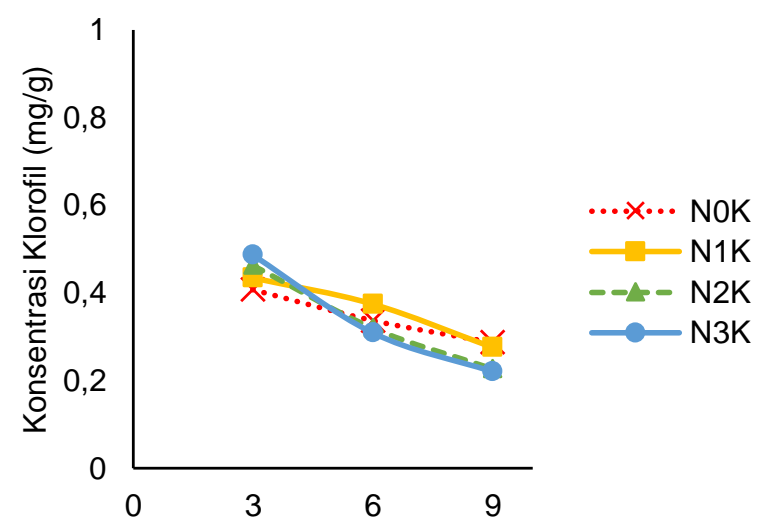

(c) Waktu (Minggu setelah tanam inang)

Gambar 5 Konsentrasi klorofil bibit cendana dengan inang primer Alternanthera sp. (a), dengan inang primer Portulaca sp. (b), dan tanpa inang primer (c), pada setiap kondisi naungan (NO = Tanpa paranet, $\mathrm{N} 1=$ Paranet $25 \%, \mathrm{~N} 2=$ Paranet $50 \%$, dan N3 = Paranet 75\%). 
kan dengan faktor naungan, namun pemberian naungan dapat meningkatkan pertumbuhan bibit cendana menjadi lebih baik.

Secara rata-rata, biomassa kering bibit cendana tanpa inang primer (Gambar 6c) adalah yang terendah, sementara yang ditanam dengan inang Alternanthera $\mathrm{sp}$. memiliki nilai biomassa kering tertinggi sepanjang penelitian (Gambar 6a). Biomassa kering bibit cendana yang ditanam bersama inang Alternanthera sp. yang terendah adalah pada kondisi No, sementara pemberian naungan memberikan pengaruh yang semakin baik yang ditunjukkan oleh nilai tertingggi pada kondisi N2, dan uji DMRT membuktikan bahwa kondisi N2 dan N3 tidak berbeda nyata (yang ditunjukkan juga oleh garis yang berhimpitan).

Bibit cendana dengan inang Portulaca sp. (Gambar 6b) memiliki biomassa yang rendah apabila ditanam tanpa naungan, namun naungan yang berlebih juga memberikan efek yang buruk. Hal ini sejalan dengan pengaruh naungan pada konsentrasi klorofil bibit cendana yang ditanam dengan Portulaca sp. (Gambar $5 b)$. Biomassa tertinggi bibit cendana yang ditanam dengan Portulaca sp. ketika berumur $6 \mathrm{MSTI}$ adalah pada kondisi N2, namun ketika memasuki $9 \mathrm{MSTI}$ kondisi N1 yang memberikan pengaruh paling baik (Gambar 6b). Fenomena ini terjadi berkaitan dengan fase pertumbuhan Portulaca sp.

Tanaman Portulaca sp. merupakan tanaman sukulen yang masuk ke dalam kategori tanaman C4 (Koch \& Kennedy 1980), artinya tanaman ini akan bertumbuh baik pada kondisi radiasi penuh. Inang primer Portulaca sp. mengalami pembungaan ketika berumur 4-5 MST, dan kemudian kembali ke fase vegetatif. Ketika kembali bertumbuh, tanaman Portulaca sp. di bawah naungan N2 dan N3 tidak dapat bertumbuh secara baik akibat radiasi yang diterima rendah. Inang Portulaca sp. pada kondisi NO bertumbuh sangat baik dan menyebabkan kompetisi dengan bibit cendana sehingga pada kondisi NO tidak terjadi hemiparasit secara baik antara bibit cendana

Tabel 1 Jumlah haustoria bibit cendana tanpa inang (K), dengan inang primer Alternanthera sp. (CA), dan dengan inang primer Portulaca sp. (CP) pada tiap tingkatan naungan

\begin{tabular}{ccccc}
\hline \multirow{2}{*}{ Naungan (N) } & \multicolumn{3}{c}{ Inang (I) } & \multirow{2}{*}{ Rerata (N) } \\
\cline { 2 - 4 } & $\mathrm{K}$ & $\mathrm{CA}$ & $\mathrm{CP}$ & \\
\hline N0 & $15^{\mathrm{aA}}$ & $67^{\mathrm{aC}}$ & $35^{\mathrm{aB}}$ & $39^{\mathrm{a}}$ \\
N1 & $16^{\mathrm{aA}}$ & $70^{\mathrm{aC}}$ & $31^{\mathrm{aB}}$ & $39^{\mathrm{a}}$ \\
N2 & $17^{\mathrm{aA}}$ & $84^{\mathrm{aC}}$ & $29^{\mathrm{aB}}$ & $43^{\mathrm{a}}$ \\
N3 & $12^{\mathrm{aA}}$ & $90^{\mathrm{aC}}$ & $30^{\mathrm{aB}}$ & $44^{\mathrm{a}}$ \\
\hline Rerata (I) & $15^{\mathrm{A}}$ & $78^{\mathrm{C}}$ & $31^{\mathrm{B}}$ & \\
\hline
\end{tabular}

Keterangan: Angka-angka yang diikuti oleh huruf yang sama adalah tidak berbeda nyata pada uji DMRT $(0,05)$. Huruf Kapital menyatakan perbandingan pada baris yang sama, dan huruf kecil menyatakan perbandingan pada kolom yang sama. $\mathrm{N} 0=$ Tanpa naungan, $\mathrm{N} 1=$ Paranet 25\%, N2 = Paranet 50\%, N3 = Paranet $75 \%$, dan curah hujan selama penelitian. dengan Portulaca sp. Keberadaan naungan N1 adalah yang paling menguntungkan untuk pembentukan hemiparasit bibit cendana dan inang Portulaca sp. tanpa menekan pertumbuhan cendana. Hal inilah yang menyebabkan biomassa bibit cendana yang ditanam dengan Portulaca sp. pada kondisi $\mathrm{N} 1$ memiliki nilai yang tinggi pada saat $9 \mathrm{MSTI}$.
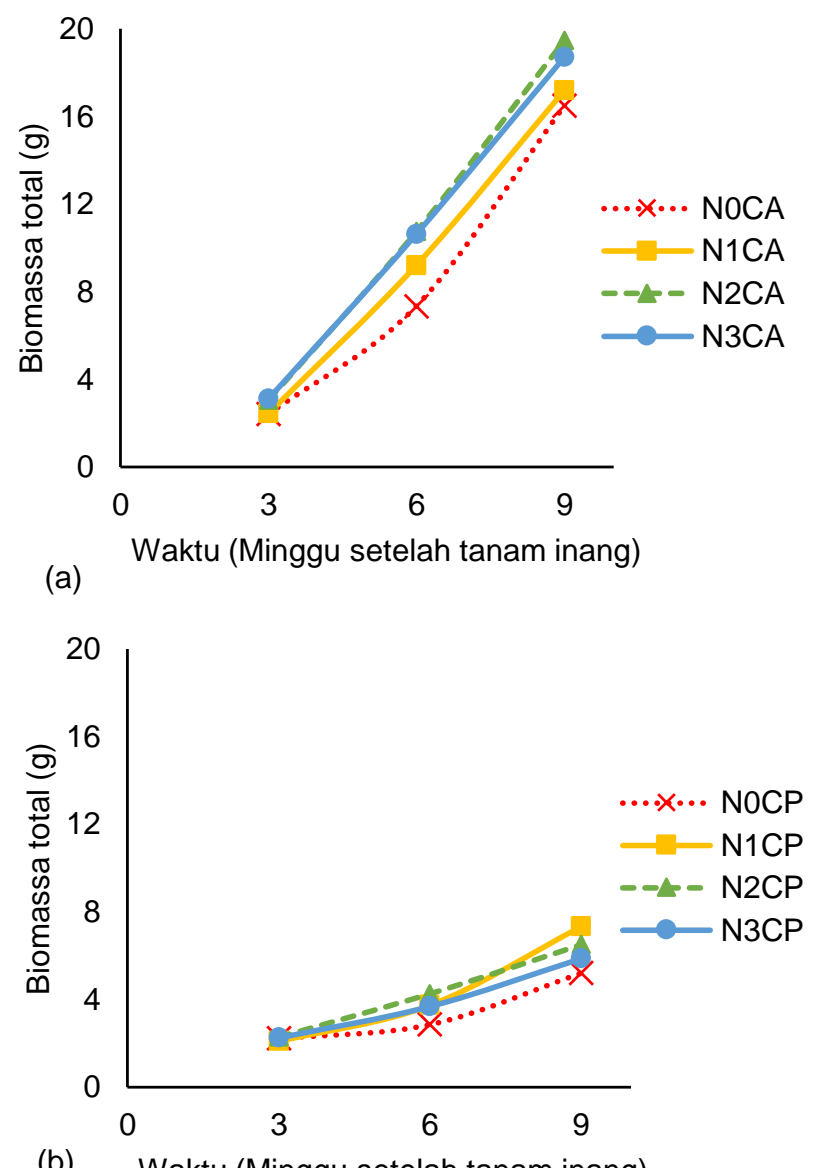

(b) Waktu (Minggu setelah tanam inang)

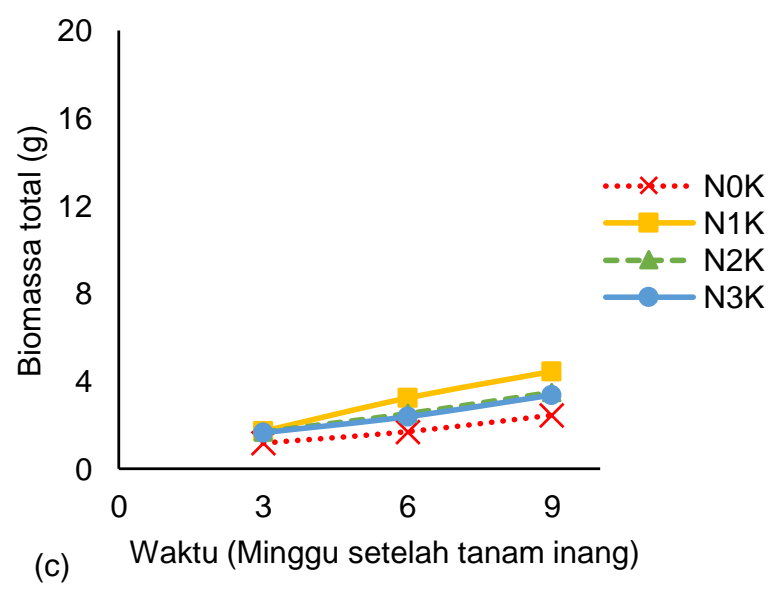

Gambar 6 Biomassa kering bibit cendana dengan inang primer Alternanthera sp. (a), dengan inang primer Portulaca sp. (b), dan tanpa inang primer (c), pada setiap kondisi naungan (N0 = Tanpa paranet, N1 = Paranet 25\%, N2 = Paranet 50\%, dan N3 = Paranet 75\%). 


\section{KESIMPULAN}

Inang primer Alternanthera sp. memberikan pertumbuhan yang paling baik bagi bibit cendana dan konsisten pada setiap parameter yang diamati dibandingkan dengan bibit cendana yang ditanam Bersama dengan Portulaca sp. Pemberian naungan dapat meningkatkan pertumbuhan bibit cendana, namun harus disesuaikan dengan kebutuhan intensitas radiasi oleh jenis inang primer yang digunakan. Bibit cendana yang ditanam dengan inang primer Alternanthera sp. bertumbuh paling baik pada kondisi paranet 50 dan $75 \%$, yaitu pada rata-rata radiasi sebesar 9,86-12,17 MJ/m²/hari. Bibit cendana yang ditanam dengan inang primer Portulaca sp. bertumbuh paling baik pada kondisi naungan paranet $25 \%$, yaitu pada rata-rata radiasi sebesar $13,62 \mathrm{MJ} / \mathrm{m}^{2} /$ hari. Penanaman bibit cendana tanpa inang primer dan tanpa naungan akan memberikan pengaruh yang buruk bagi pertumbuhan bibit cendana.

\section{DAFTAR PUSTAKA}

Anyia AO, Herzog H. 2004. Water-use efficiency, leaf area and leaf gas exchange of cowpeas under midseason drought. European Journal of Agronomy. 20: 327-339. https://doi.org/10.1016/S1161-0301 (03)00038-8

Arun Kumar AN, Joshi G, Mohan Ram HY. 2012. Sandalwood: History, uses, present status and the future. Current Science. 103(12): 1408-1416.

Bergez JE, Dupraz C. 2000. Effect of ventilation on growth of Prunus avium seedlings grown in treeshelters. Agricultural and Forest Meteorology. 104: 199-214. https://doi.org/10.1016/S01681923(00)00163-5

Boer R, June T. 2001. Analisis Kesesuaian Iklim untuk Pengembangan Cendana (Santalum album L.) di Nusa Tenggara Timur. Berita Biologi. 5(5): 581-591.

Dhanya B, Viswanath S, Purushothman S. 2010. Sandal (santalum album L.) conservation in Southern India: A review of policies and their impacts. Journal of Tropical Agriculture. 48(1-2): 1-10.

Erkan N. 2012. Antioxidant activity and phenolic compounds of fractions from Portulaca oleracea $\mathrm{L}$. Food Chemistry. 133(3): 775-781. https://doi.org/ 10.1016/j.foodchem.2012.01.091

FanggidaE YR, Impron. 2018. Evapotranspiration of Sandalwood (Santalum Album L.) Seedlings with Several Primary Host Plants. Agromet. 32(1): 2130. https://doi.org/10.29244/j.agromet.32.1.21-30

Hiscox JD, Israelstam GF. 1979. A method for the extraction of chlorophyll from leaf tissue without maceration. Canadian Journal of Botany. 57(12): 1332-1334. https://doi.org/10.1139/b79-163

Husaeni EA, Sudaryanto. 2001. Silvikultur Cendana: Mencari luasan Budi daya Yang Layak Ekologis Dan Ekonomis. Berita Biologi. 5(5): 1-13.

Koch KE, Kennedy RA. 1980. Characteristics of Crassulacean Acid Metabolism in the Succulent C4 Dicot, Portulaca oleracea L. Plant Physiology. 65: 193-197. https://doi.org/10.1104/pp.65.2.193

Njurumana GN, Marsono D, Irham, Sadono R. 2014. Konservasi cendana (Santalum album Linn) berbasis masyarakat pada sistem kaliwu di Pulau Sumba. Jurnal Ilmu Lingkungan. 11(2): 51-61. https://doi.org/10.14710/jil.11.2.51-61

Rahayu S, Wawo AH, Noordwijk M van, Hairiah K. 2002. Cendana, Deregulasi dan Strategi Pengembangannya. Bogor (ID): World Agroforestry Centre-ICRAF.

Shehata S, Elsagheer AA, El-Helaly MA, Saleh SA, Abdallah AM. 2013. Shading effect on vegetative and fruit characters of tomato plant. Journal of Applied Sciences Research. 9(3): 1434-1437.

Surata IK. 1993. Pengaruh jenis inang terhadap pertumbuhan semai cendana (Santalum album L.). Santalum. 9: 1-9. https://doi.org/10.18330/ jwallacea.2012.vol1iss1pp13-25

Surata IK. 2012. Pertumbuhan Semai Cendana (Santalum album Linn.) pada Beberapa Ukuran Kantung Plastik di Daerah Semiarid. Jurnal Penelitian Kehutanan Wallacea. 1(1): 13-25. https://doi.org/10.1007/s11842-008-9057-z

Surata IK, Butarbutar T. 2008. Shading system on sandalwood seedlings in Timor, East Nusa Tenggara, Indonesia. Small-Scale Forestry. 7(3-4): 311-318.

Tennakoon KU, Cameron DD. 2006. The anatomy of Santalum album (Sandalwood) haustoria. Can $J$ Bot. 84(10): 1608-1616. https://doi.org/10.1139/ b06-118

Wawo AH. 2004. Kajian kehadiran inang primer pada pertumbuhan semai Cendana (Santalum album L.). Biota. 9(2): 114-118.

Wawo AH. 2009. Pengaruh Jumlah Semai Akasia (Acacia villosa) dan Lamtoro Lokal (Leucaena glauca) Sebagai Inang Primer Cendana (Santalum album L.). Bul Littro. 20(1): 50-58.

Yang X, Zhang X, Teixeira da Silva JA, Liang K, Deng R, Ma G. 2014. Ontogenesis of the collapsed layer during haustorium development in the root hemiparasite Santalum album Linn. Plant Biology. 16(1): 282-290. https://doi.org/10.1111/plb.12026 